\title{
Morphometrics and Body Condition Index of Eurasian Collared-Dove and Mourning Dove in Durango, Mexico
}

\author{
Manuel Armando Salazar-Borunda ${ }^{1}$, José Hugo Martínez-Guerrero ${ }^{2 *}$, \\ Martín Emilio Pereda-Solís ${ }^{2}$ \\ ${ }^{1}$ Student of Master Program MICAF-UJED, Facultad de Medicina Veterinaria y Zootecnia, Universidad Juárez del \\ Estado de Durango, Durango, México \\ ${ }^{2}$ Cuerpo Académico de Fauna Silvestre, Facultad de Medicina Veterinaria y Zootecnia, Universidad Juárez del \\ Estado de Durango, Durango, México \\ Email: borunda@ujed.mx, ${ }^{*}$ che hugo1@hotmail.com, conplandg@hotmail.com
}

Received 18 January 2015; accepted 6 February 2015; published 10 February 2015

Copyright (C) 2015 by authors and Scientific Research Publishing Inc.

This work is licensed under the Creative Commons Attribution International License (CC BY). http://creativecommons.org/licenses/by/4.0/

\section{c) (i) Open Access}

\begin{abstract}
In order to incorporate the knowledge of two species of wild doves and compare the results of both, we assessed morphometrics (body weight, bill, tarsus, tail, wing, head and culmen length) and body condition index (using weigh, wing, tail and tarsus length) of Eurasian Collared-Dove Streptopelia decaocto and Mourning Dove Zenaida macroura (Aves: Columbidae) based on 40 specimens of each species collected during fall-winter 2013 and spring-summer 2014 in the municipality of Durango, Durango, Mexico. We found that body condition index was higher during fallwinter for both species. We also found size dimorphism. Males of Eurasian Collared-Dove were larger than females in head length $(p=0.002)$ and tail length $(p=0.05)$ but smaller in culmen length. Female Mourning Doves had a higher body condition index compared to males $(p=0.02)$ during both seasons. As expected, Eurasian Collared-Dove was larger in all measurements than Mourning Dove $(p>0.05)$ but tail length $(p=0.12)$.
\end{abstract}

\section{Keywords}

Morphometrics, Eurasian Collared-Dove, Streptopelia decaocto, Mourning Dove, Zenaida macroura

\section{Introduction}

There are 18 species of pigeons and doves (Aves: Columbidae) native to Mexico and two introduced ones [1].

\footnotetext{
${ }^{*}$ Corresponding author.
}

How to cite this paper: Salazar-Borunda, M.A., Martínez-Guerrero, J.H. and Pereda-Solís, M.E. (2015) Morphometrics and Body Condition Index of Eurasian Collared-Dove and Mourning Dove in Durango, Mexico. Open Journal of Ecology, 5, 33-38. http://dx.doi.org/10.4236/oje.2015.52004 
The Eurasian Collared-Dove (Streptopelia decaocto) is, as its name implies, originally from Eurasia and introduced in Florida in the 1990s [2]. Its population has been increasing and expanded its distribution to the west and now has reached Mexico [3]. Its preferred habitat is suburban and now occurs all along Mexico [4] [5]. As an introduced species, it may represent a threat to the structure, function and integrity of ecosystems [6] as it might be able to modify the environment and even bring to extinction to native species [7]. Although not all introduced species become invaders, their potential effects as an exotic species are unpredictable so it is necessary to acknowledge their biology to effectively control them [6]. The Mourning Dove (Zenaida macroura) is native to Mexico as a resident species with a stable population of no concern [1].

The Eurasian Collared-Dove and Mourning Dove, hereafter STRDEC and ZENMAC, respectively, have different sizes and morphometrics and some of them, as body size, may be related to survival [8], and also to behavior, ecology and physiology [9] [10]. Some of these measurements, as weight, vary through time accordingly to environmental conditions such as resource availability and time of the year [11], which remarks the importance to assess those variables through the seasons and get information to know those species more in depth. For these reasons, the goal of this study was to characterize and to compare morphometrics and body condition index (BCI) for both species through the annual cycle.

\section{Materials and Methods}

\subsection{Study Area}

This study was carried out in the south-central part of the Municipality of Durango, in the state of Durango, Mexico between coordinates $23^{\circ} 58^{\prime} 15.9^{\prime \prime}$ and $23^{\circ} 57^{\prime} 26.3^{\prime \prime}$ latitude north and $104^{\circ} 30^{\prime} 18.0^{\prime \prime}$ and $104^{\circ} 34^{\prime} 11.4^{\prime \prime}$ longitude east. Climate is temperate with summer rains (Cw) [12].

\subsection{Materials}

We collected 40 specimens of each species during fall-winter of 2013 and spring-summer 2014 (collecting permit No. SGPA/DGVS/12294/13), after procedures set by the North American Banding Council (2001).

We measured the following variables: body weight in grams, and bill length (culmen), tarsus length, and wing and tail length in mm. Weight was measured with a Radwag ${ }^{\circledR}$ analytical balance model WPT1C/1 scale $0.01 \mathrm{~g}$ accuracy and tarsus and head lengths were measured with a Surtek ${ }^{\circledR}$ dial caliper model 122202 with $0.01 \mathrm{~mm}$ accuracy, for wing and tail we used a Avinet ${ }^{\circledR} 15 \mathrm{~cm}$ wing and tail ruler model WING15ECON.

\subsection{Methods}

In addition, we measured the distance from distal end of parietal to the premaxilla (head length), distance from the rostral end of the premaxilla to the tip of the bill (bill length) and distance from the nares to the tip of the bill (culmen length). Tarsus length was measured from the joint of the femur to the joint of the feet. Wing length was measured folded from the bend of the wing to the largest primary and tail length from the base to the tip of the largest rectrix [13].

We used the following body condition indexes (BCI):

$$
\begin{aligned}
& \text { [14] ICC = weight }(\mathrm{g}) / \text { wing length }(\mathrm{mm}) . \\
& \text { [15] ICC }=\text { weight }(\mathrm{g}) \times 100 / \text { wing length }(\mathrm{mm}) . \\
& \text { [16] ICC }=\text { weight }(\mathrm{g}) / \text { wing length } \times \text { tail length } \times \text { tarsus length }
\end{aligned}
$$

\subsection{Statistical Analyses}

We used SAS [17] for basic statistics (proc UNIVARIATE) and we compared variables for both species by season and sex (proc ANOVA) after [18]. We performed a posteriori Tukey's test with a $\mathrm{p}>0.05$ for significance level.

\section{Results and Discussion}

\subsection{Seasonality}

We found that STRDEC was larger than ZENMAC for all the variables measured but tail length (Table 1). The 
Table 1. Morphometrics measurements of Eurasian Collared-Doves and mourning doves during two seasons springsummer (SS) and fall-winter (FW) in the municipality of Durango, Mexico.

\begin{tabular}{|c|c|c|c|c|c|c|c|c|c|}
\hline Species & Season & Sex & $\begin{array}{l}\text { Weight } \\
\text { (g) }\end{array}$ & $\begin{array}{l}\text { Head } \\
(\mathrm{mm})\end{array}$ & $\begin{array}{l}\text { Culmen } \\
(\mathrm{mm})\end{array}$ & $\begin{array}{l}\text { Bill } \\
(\mathrm{mm})\end{array}$ & $\begin{array}{l}\text { Tarsus } \\
(\mathrm{mm})\end{array}$ & $\begin{array}{l}\text { Wing } \\
(\mathrm{mm})\end{array}$ & $\begin{array}{l}\text { Tail } \\
(\mathrm{mm})\end{array}$ \\
\hline \multirow{4}{*}{ STRDEC } & \multirow{2}{*}{ SS } & M & 176.75 & $47.4^{\mathrm{a}}$ & 16.1 & 10.7 & 27.0 & 175.8 & 130.3 \\
\hline & & F & 169.11 & $43.8^{\mathrm{b}}$ & 16.9 & 10.5 & 27.0 & 171.5 & 124.0 \\
\hline & \multirow{2}{*}{ FW } & M & 166.58 & 47.1 & 17.7 & 12.4 & 28.3 & 170.5 & 134.2 \\
\hline & & $\mathrm{F}$ & 149.88 & 44.3 & 18.0 & 11.7 & 26.7 & 160.8 & 129.5 \\
\hline \multirow{4}{*}{ ZENMAC } & \multirow{2}{*}{ SS } & M & 112.31 & 40.4 & 13.9 & 9.1 & 24.4 & $150.9^{\mathrm{a}}$ & $126.0^{\mathrm{a}}$ \\
\hline & & $\mathrm{F}$ & 120.20 & 41.9 & 14.2 & 9.7 & 23.8 & $143.0^{\mathrm{b}}$ & $120.4^{\mathrm{b}}$ \\
\hline & \multirow{2}{*}{ FW } & M & 115.71 & $42.3^{\mathrm{a}}$ & $14.6^{\mathrm{a}}$ & 11.1 & 23.6 & $148.6^{\mathrm{a}}$ & $138.3^{\mathrm{a}}$ \\
\hline & & F & 113.58 & $40.3^{b}$ & $13.6^{\mathrm{b}}$ & 10.1 & 23.0 & $142.2^{\mathrm{b}}$ & $123.1^{\mathrm{b}}$ \\
\hline
\end{tabular}

Same letter shows no statistical difference; Tukey’s test ( $<<0.05)$; M: males; F: females.

body condition index did not show significant differences between seasons (Table 2) which may be related to substantial food availability during the whole year.

Previous studies have found these species to be generalists, studying ZENMAC [19] and STRDEC [20]. However, some other studies [21] [22] have found that STRDEC may consume some small invertebrates that contain protein of higher biological value.

Both species had a higher BCI during fall-winter, seasons coinciding with harvesting of some crops such as corn (Zea mays), and sorghum (Sorghum spp.), among others, suggesting that both species had access to resources of higher biological quality. In addition, migratory behavior of ZENMAC is benefited as doves can deposit more fat [23] resulting in higher weight.

Size and BCI of STRDEC was always higher than ZENMAC during both season, probably because of differences inherent to the species, which suggests that STRDEC may have a higher survival [8].

\subsection{Size Dimorphism}

The body condition index and morphometrics for male STRDEC were always higher than in females for both seasons ( $p=0.05)$, as is well established by several authors [24] [25]. In addition some studies have found that physical condition and weight is related to androgen levels in males [26]. We also found significant differences in head $(p=0.002)$ and tail $(p=0.05)$ length between males and females, except for culmen length.

In ZENMAC, we found sexual dimorphism in weight, as found by [27]. However, we found a higher BCI in females compared to males $(p=0.021)$ during both seasons, suggesting that females are more able to get food resources or more properly, it may be related to egg production. Length measurements were higher in males than in females, in head $(p=0.006)$ and culmen $(p=0.026)$ length during fall-winter and wing $(p=0.01)$ and tail ( $p$ $=0.03$ ) length during both seasons (Table 1 ).

\subsection{Species Comparisons}

Most morphometrics measurements (Table 3 ) and BCI showed significant differences $(\mathrm{p}<0.001)$ but tail length $(p=0.124)$. STRDEC weight coincides with the reported in the Netherlands [24] (range 162.0 - $243.7 \mathrm{~g}$ ) but it was lower than the one reported for some other sites in North America [25] (range 160.0 - $180.3 \mathrm{~g}$ ).

Tail length of doves collected in Durango $(10.4-14.9 \mathrm{~cm})$ was higher than for other sites in North America $(13.4-13.8 \mathrm{~cm})$ but similar to those of the Netherlands $(12.9-14.7 \mathrm{~cm})$. Tarsus length also was higher in Durango $(2.2-3.6 \mathrm{~cm})$ than in other sites of both North America [25] and the Netherlands [24]. Body weight of ZENMAC (93.9 - 144.85 g) was closer to Marginella subspecies (86 - 142 g [27]) than to Caroliniensis (100 170 [28]).

STRDEC is a larger dove tan ZENMAC during both seasons, of course. Higher tolerance to human presence by STRDEC [29] compared to ZENMAC makes the species more abundant all year round as they have food 
Table 2. Body condition index of Eurasian Collared-Doves and mourning doves during two seasons spring-summer and fall-winter in the municipality of Durango, Mexico.

\begin{tabular}{|c|c|c|c|c|}
\hline \multirow{2}{*}{ Species } & \multirow{2}{*}{ Sex } & \multicolumn{3}{|c|}{ Body condition index } \\
\hline & & ICC 1 & ICC 2 & ICC 3 \\
\hline \multirow{2}{*}{ STRDEC (SS) } & M & 1.0063 & $0.0033^{\mathrm{a}}$ & 335.0738 \\
\hline & $\mathrm{F}$ & 0.9874 & $0.0034^{\mathrm{b}}$ & 327.1880 \\
\hline \multirow{2}{*}{ ZENMAC (SS) } & M & $0.7450^{\mathrm{b}}$ & $0.0033^{b}$ & 232.8017 \\
\hline & $\mathrm{F}$ & $0.8405^{\mathrm{a}}$ & $0.0042^{\mathrm{a}}$ & 253.5608 \\
\hline \multirow{2}{*}{ STRDEC (FW) } & M & 0.9723 & $0.9723^{\mathrm{a}}$ & 362.8501 \\
\hline & $\mathrm{F}$ & 0.9224 & $0.9224^{\mathrm{b}}$ & 305.2384 \\
\hline \multirow{2}{*}{ ZENMAC (FW) } & M & $0.7801^{\mathrm{b}}$ & $0.0036^{\mathrm{b}}$ & $249.5939^{b}$ \\
\hline & $\mathrm{F}$ & $0.8016^{\mathrm{a}}$ & $0.0040^{\mathrm{a}}$ & $242.4716^{\mathrm{a}}$ \\
\hline
\end{tabular}

Body condition index: 1 [13], 2 [14], 3 [15]; same letter shows no statistical difference; Tukey’s test (p < 0.05); M: male; F: females; SS: springsummer season; FW: fall-winter season.

Table 3. Morphometrics of Eurasian Collared-Dove and mourning doves in the municipality of Durango, Mexico.

\begin{tabular}{cccccccc}
\multirow{2}{*}{ Species } & \multicolumn{7}{c}{ Morphometrics } \\
\cline { 2 - 8 } & Weight (g) & Head (mm) & Culmen (mm) & Bill (mm) & Tarsus (mm) & Wing (mm) & Tail (mm) \\
\hline \multirow{2}{*}{ STRDEC } & 108.94 & 40.0 & 150.0 & 10.0 & 22.0 & 142.0 & 104.0 \\
& 204.74 & 52.0 & 24.0 & 14.0 & 36.0 & 186.0 & 149.0 \\
& \pm 25.41 & \pm 3.60 & \pm 2.00 & \pm 1.30 & \pm 2.70 & \pm 11.1 & \pm 10.90 \\
\multirow{2}{*}{ ZENMAC } & 93.80 & 34.0 & 10.0 & 7.0 & 21.0 & 123.0 & 95.0 \\
& 144.85 & 50.0 & 20.0 & 13.0 & 26.0 & 170.0 & 147.0 \\
& \pm 11.51 & \pm 2.50 & \pm 1.70 & \pm 1.50 & \pm 1.30 & \pm 9.80 & \pm 13.80 \\
\hline
\end{tabular}

\pm : standard deviation of the morphometric variable.

resources provided by human populations [5]. Body size and its aggression towards other species [2] make STRDEC able to outcompete other dove species such as ZENMAC [30].

\section{Conclusions}

We found that body measurements were different between both dove species and also some size dimorphism of some but not all of these measurements such as head and bill length and body condition index. Indeed, Streptopelia decaocto is larger than Zenaida macroura and we have found that season has some influence on body condition index for both species.

Morphometric measurements reported in this species in contrast to some other parts of the world suggest that morphology might be influenced by historical or geographical factors, such that environment is shaping morphology through adaptation, probably linked to habitat selection or feeding and its modifications caused by human activities. So, we conclude by stating that more studies on populations in other regions should be carried out to test these ideas.

\section{References}

[1] Rocha, G., Rodríguez, B. and Antaño, D. (2009) Plan de manejo tipo de palomas. Secretaría de Medio Ambiente y Recursos Naturales.

http://www.semarnat.gob.mx/archivosanteriores/temas/gestionambiental/vidasilvestre/Documents/PMT_Dic_2009/PM T\%20PALOMAS.pdf 
[2] Johnson, S.A. and Donaldson, G.F. (2012) Florida’s Introduced Birds: Eurasian Collared-Dove (Streptopelia decaocto). Department of Wildlife Ecology and Conservation, University of Florida, Gainesville. http://edis.ifas.ufl.edu/uw301

[3] Blancas, C.E., Torres, C.B. and Hernández, B.J. (2014) Presencia de la paloma turca (Streptopelia decaocto) y africana de collar (Streptopelia roseogrisea) en el Estado de Guerrero, México. Huitzil, 15, 10-16.

[4] Contreras, A. and Ruiz, G. (2010) Primer informe de leucismo en la paloma de collar Streptopelia decaocto (Columbiformes), especie exótica en México. Cuadernos de Investigación Científica UNED, 3, 85-88.

[5] Chablé, J., Gómez, E. and Hernández, S. (2012) Registros reproductivos de la paloma de collar (Streptopelia decaocto) en Yucatan, México. Huitzil, 13, 5.

[6] Naranjo, E.J. and Dirzo, R. (2009) Impacto de los factores antropogénicos de afectación directa alaspoblaciones silvestres de flora y fauna. Conabio, México: Capital natural de México, estado de conservación y tendencias de cambio, Vol. 2, 247-276.

[7] Wilkove, D., Rothstein, D., Dubow, J. and Losos, E. (1998) Quantifying Threats to Imperiled Species in the United States. BioScience, 48, 607. http://dx.doi.org/10.2307/1313420

[8] Speakman, J.R. (2005) Body Size, Energy Metabolism and Lifespan. The Journal of Experimental Biology, 208, 17171730. http://dx.doi.org/10.1242/jeb.01556

[9] Peters, H. (1986) The Ecological Implications of Body Size. Cambridge University Press, Cambridge.

[10] Reiss, M.J. (1989) The Allometry of Growth and Reproduction. Cambridge University Press, Cambridge. http://dx.doi.org/10.1017/CBO9780511608483

[11] Atkinson, C.T., Thomas, N.J. and Hunter, B.D. (2008) Parasitism: Cost and Effects. In: Parasitic Disease of Wild Birds, Wiley-Blackwell, Hoboken, 595.

[12] García, E. (1998) Modificaciones al sistema de clasificación climática de Köppen. Instituto de geografía. Universidad Nacional Autónoma de México, México City.

[13] Pyle, P. (1997) Identification Guide to North America Birds. Part I: Columbidae to Ploceidae. Slate Creek Press, Point Reyes Station.

[14] Ringelman, J.K. and Szymczak, M.R. (1985) A Physiological Condition Index for Wintering Mallards. The Journal of Wildlife Management, 49, 564-568. http://dx.doi.org/10.2307/3801672

[15] Winker, K., Warner, D.W. and Weisbrod, A.R. (1992) Daily Mass Gain among Woodland Migrants at an Inland Stopover Site. The Auk, 109, 853-862. http://dx.doi.org/10.2307/4088159

[16] Delong, J. and Gessaman, J.A. (2001) A Comparison of Noninvasive Techniques for Estimating Total Body Fat in Sharp-Shinned and Cooper Hawks. Journal of Field Ornithology, 72, 349-364. http://dx.doi.org/10.1648/0273-8570-72.3.349

[17] SAS Institute Inc. (2009) Cary.

[18] Steel, G.R. and Torrie, J.H. (1986) Bioestadística: Principios y procedimientos. McGraw-Hill, Mexico City.

[19] Mirarchi, R.E., Baskett, T., Sayre, M.W. and Tomlinson, R.E. (1993) Ecology and Management of the Mourning Dove. Growth, Maturation, and Molt. A Wildlife Management Institute, Washington DC.

[20] Romagosa, C.M. and Labiski, R.F. (2000) Establishment and Dispersal of the Eurasian Collared-Dove in Florida. Journal of Field Ornithology, 7, 159-166. http://dx.doi.org/10.1648/0273-8570-71.1.159

[21] Rana, B.D. (1975) Breeding Biology of the Indian Ring Dove in the Rajasthan Desert. The Auk, 92, 322-332. http://www.jstor.org/stable/4084560

[22] Saini, H.K. (1993) Maggots in the Diet of the Collared Dove. Bulletin of British Ornithology Club, 113, $263-264$.

[23] Jenkins, J.H. (1955) A Contribution to the Physiological Ecology of the Mourning Dove, Zenaida macroura carolinensis (Linnaeus): A Study of Age and Seasonal Changes in Feathers, Gonads, Weight, and Lipid Deposition. Dissertation, University of Georgia, Athens.

[24] Cramp, S. (1985) The Birds of the Western Palearctic. Vol. IV, Oxford University Press, Oxford.

[25] Smith, P.W. and Kale, H.W. (1986) Eurasian Collared-Doves Collected in Florida. Florida Field-Natural, 14, $104-107$.

[26] Rodríguez, P.A. (2008) Señales fiables en la perdíz roja (Alectoris rufa): Condición física, testosterona y carotenoides. Ph.D. Universidad de Castilla la Mancha e Instituto de Investigación en Recursos Cinegéticos, Albacete.

[27] Otis, D.L., John, H., Schulz, D., Mararchi, R.E. and Baskett, T.S. (2008) Mourning Dove (Zenaida macroura). The Birds of North America. Cornell Lab of Ornithology, Ithaca. http://bna.birds.cornell.edu.bnaproxy.birds.cornell.edu/bna/specie

[28] Lucas, J. and Freeberg, T.M. (2006) Fecal Corticosterone, Body Mass, and Caching Rates of Carolina Chickadees (Poecile carolinensis) from Disturbed and Undisturbed Sites. Hormones and Behavior, 49, 634-643. 
http://dx.doi.org/10.1016/j.yhbeh.2005.12.012

[29] Ikuko, F., Pearl, E. and Mazzoti, F. (2010) The Rapid Spread of Invasive Eurasian Collared Doves (Streptopelia decaocto) in the Continental USA Follows Human-Altered Habitats. The International Journal of Avian Science, 152, 622-632.

[30] Poling, T. and Hayslette, E.S. (2006) Dietary Overlap and Foraging Competition between Mourning Doves and Eurasian-Collared Doves. Journal of Wildlife Management, 70, 998-1004.

http://dx.doi.org/10.2193/0022-541X(2006)70[998:DOAFCB]2.0.CO;2 
Scientific Research Publishing (SCIRP) is one of the largest Open Access journal publishers. It is currently publishing more than 200 open access, online, peer-reviewed journals covering a wide range of academic disciplines. SCIRP serves the worldwide academic communities and contributes to the progress and application of science with its publication.

Other selected journals from SCIRP are listed as below. Submit your manuscript to us via either submit@scirp.org or Online Submission Portal.
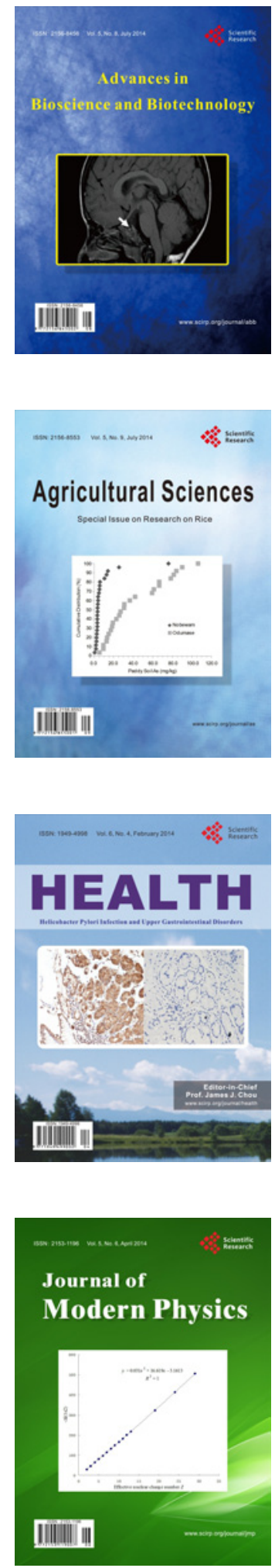
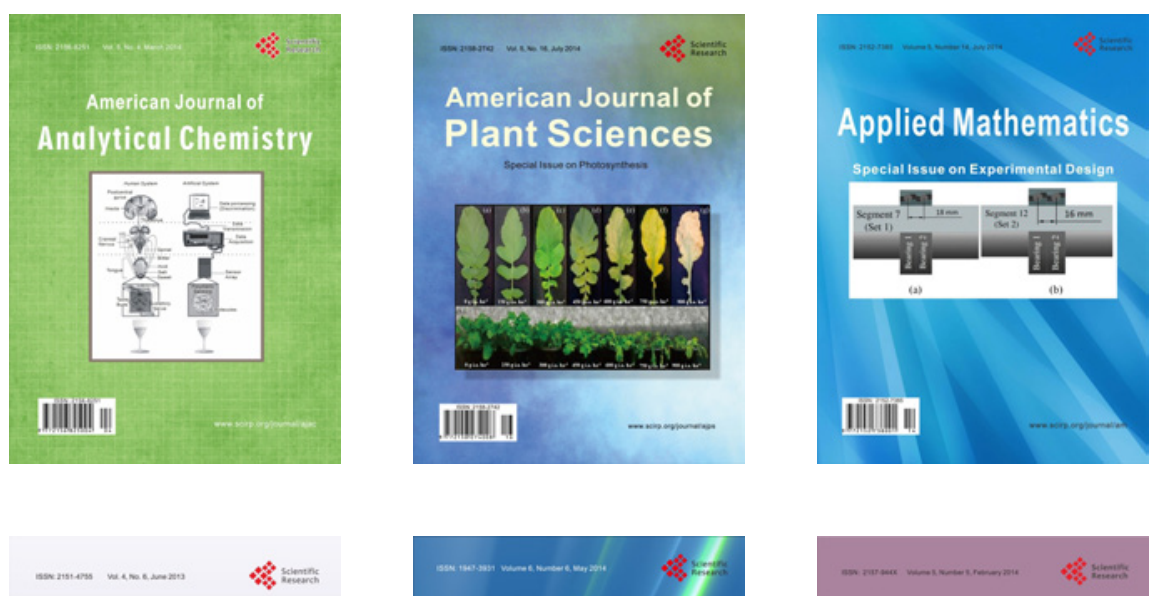

Creative Education
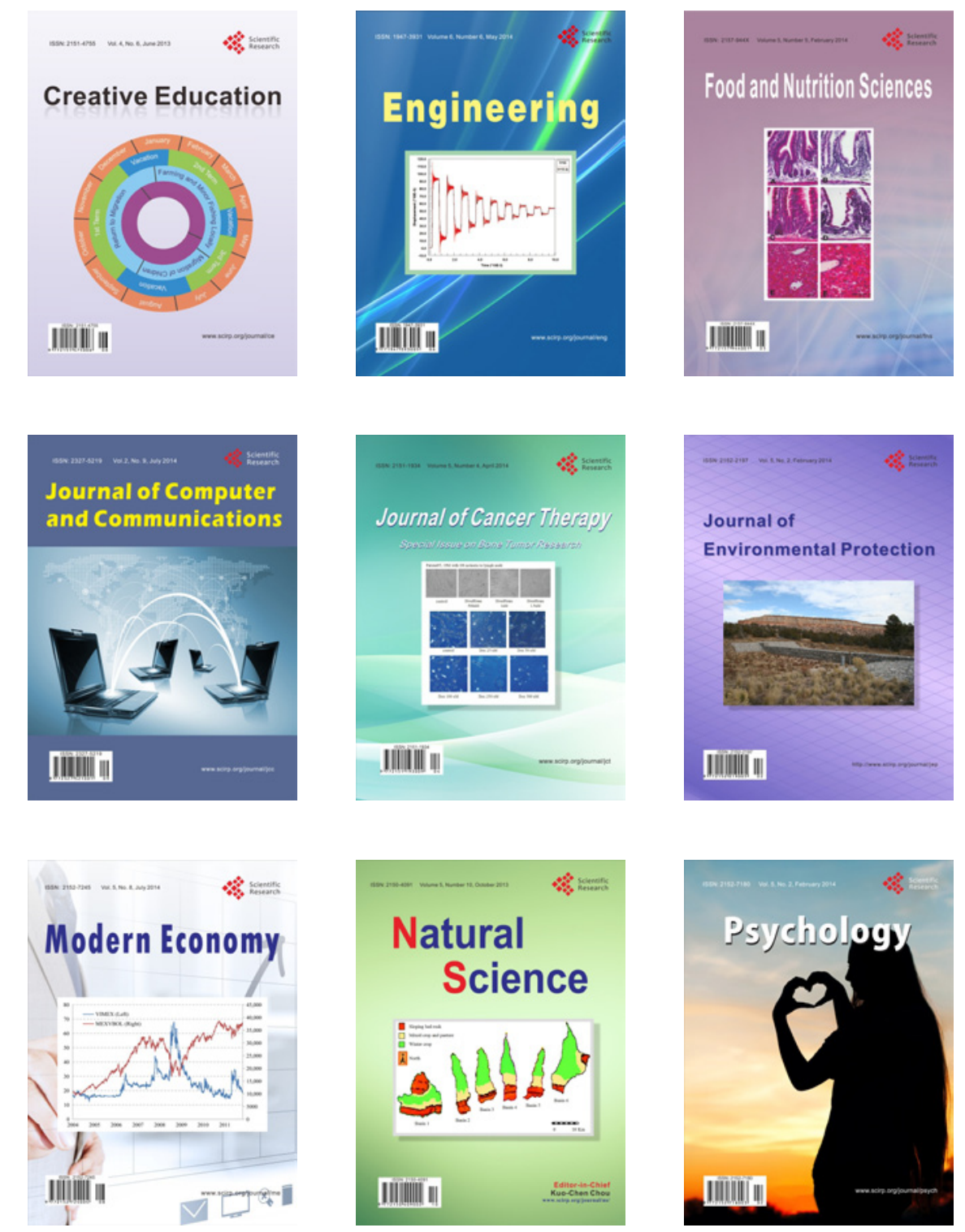